\title{
E-solidarity, a means of fighting against FGM (Female Genital Mutilation) \\ Project proposal
}

\author{
Annie Corsini-Karagouni \\ Maasai Education Discovery Committee Member, 38, Ch. Edouard Olivet 1226 Thônex, \\ Switzerland, tel. 0041-22-348.33.70
}

corsini_annie@yahoo.fr

Abstract: This project aims to contribute to the eradication of the practice of Female Genital Mutilation (FGM) throughout the Maasailand in Kenya in agreement with the World Health Organisation (WHO) policy by large-scale distribution of information to the remote Maasai villages, by creation of awareness, by proposing alternative rituals, by improvement of the social (and economic) status of women and by encouragement of Maasai families to send female children to school. e-Society means will be used in the understanding that these are not in opposition to preserving tradition and ethnic identity

Key words: e-solidarity, ethnic identity, Female Genital Mutilation, rituals, tradition, women 


\section{OBJECTIVES}

The main objective is to contribute to the eradication of the practice of Female Genital Mutilation (FGM) throughout the Maasailand in Kenya. This is in agreement with the WHO's (World Health Organisation) policy, which targets complete worldwide eradication of FGM (African countries being of high priority) as of 2015.

Specific objectives are:

- Large-scale distribution of specific information to the remote Maasai village population. This essential information is centred on women's health, reproductive health, human rights, and the legal status of FGM.

- The creation of awareness among the Maasai community (Narok district had an estimated 365,750 people in the last population count of 1999) on this issue, while preserving to the utmost Maasai culture and identity.

- The proposition of alternative rituals to mark the rite-of-passage from childhood to adulthood of young girls (14 to 16 years old).

- The improvement of the social (and economic) status of women by generating income based on traditional handicraft production.

- The encouragement of Maasai families to send female children to school to get an education.

- Creation of an understanding that progress and development through eSociety are not in opposition to preserving tradition and ethnic identity.

\section{INITIAL CONDITIONS}

The following initial conditions should be taken into account. The Maasai community in rural areas is a pastoral and semi-nomadic one. Living conditions are harsh; there is a chronic lack of water, sanitation, and education. ICT is an unheard-of dream in these remote areas that lack electricity, communication facilities, and roads.

Other NGOs have tried to combat FGM in the past, giving seminars in the central town and inviting people to participate. This method is partially efficient, as the most vitally concerned segment of the population never receives this information.

From a legal point of view, the Constitution and the Penal Code of Kenya prohibit FGM. And even though education is compulsory, it is not a practical reality in this pastoral semi-nomadic society.

Without any doubt, strengthening the woman's social role inside the traditional Maasai family is a key step in this project. The way to achieve this is by developing and promoting the economic activity of women. 


\section{TIMETABLE OUTLINE}

The e-solidarity project includes 3 phases of action.

\section{Phase 1}

Information sessions given by health professional, volunteers and social workers in both town (Narok, the Maasailand capital in Kenya) and remote rural areas.

Access isolated villages that are off the beaten track and without electricity - areas where, to this day, e-society has no meaning.

Only personal, first-hand contact is valuable and reliable. Our visits are highly appreciated by the rural population.

\section{Phase 2}

First information is given to Masaai women about FGM, related health issues. They are being made aware of the considerable social and cultural commitment that such a decision involves. Then they organise themselves into small cooperatives that will produce traditional handicraft and Maasai beadwork such as bracelets. The MED and project leader meanwhile will identify worldwide partner web sites, which by hosting our web page would promote the anti-FGM campaign.

"Buy a Maasai bracelet and help women to say NO to FGM" will be the project identification slogan.

\section{Phase 3}

ICT becomes the connecting tool between developed and developing countries. Internet would attract and consolidate international help and propagate solidarity (by emails addressed via MED to women's groups and by selling the solidarity bracelets via the web to the international public.)

\section{RESOURCES}

To achieve the above phases of implementation, the project needs resources such as: 
- Social workers and health specialists to hold open-air seminars throughout the rural villages.

- Logistic means (a $4 \times 4$ rental car to reach remote areas), educational material (the WHO provides us with this regularly), audiovisual means (TV, DVD or laptops) to show educational films and documentation.

- A MED local coordinator must keep in touch with rural women and coordinate the promotion of the Maasai women's groups' beadwork production.

- A web master, to designing the web page of the project.

- Concerted fundraising from UNESCO, UNIFEM or other human right's institutions or governmental bodies, for the large scale kick-off (over the whole Maasailand) of the implementation of the project.

\section{PARTNERS}

The Maasai Education Discovery (MED) centre in Narok will play a pivotal role in the project. Solidarity e-mails will be received through the web and centralised there. These will then be spread (read-as the women are completely illiterate) throughout the rural community.

The MED centre will gather international orders received from web ("solidarity Maasai bracelets") then will distribute these orders among the "women's groups against FGM", and finally it will collect and ship the goods to the clients.

MED's project coordinator will distribute the production benefit back to the rural women's groups, in order to allow them to launch a new, local and sustainable economic activity. He/she also will decide the start and end point of the assistance stage.

A list of international web sites, considered as potential partners, able to host a web page advertising our project has already been compiled and some agreements have been reached:

- www.eziba.com (this site has already supported the "Peace baskets project" in Rwanda)

- www.fgmnetwork.org ("education and networking projects")

- www.feminist.org (site of "Feminist majority Foundation")

- www.soroptimist.org (International Club of mutual aid)

- www.bpw.ch (Business and professional Women)

- www.cwf.ch (Carrier Women Forum)

- www.un.org/womenwatch (UN's women)

- www.cybersolidaires.org (UN's women)

- www.femmesfrancophones.free.fr

- www.whrnet.org (Women Human Rights Net) 
- www rotary.belux.org (Rotary club) etc.

\section{EXPECTED OUTCOMES}

The following outcomes are expected:

- Break the wall of isolation wall surrounding the rural Maasai community;

- Strengthen the local economy through women's activities;

- Connect the western public with social development in the remote Maasai community;

- Develop awareness about FGM and contribute to its complete eradication;

- Encourage the education of Maasai children (the emphasis being given to girls, victims of FGM).

\section{CRITICAL SUCCESS FACTORS}

Key factors for success are:

- Good local co-ordination (MED's responsibility);

- Sufficient uptake of the project by international organisations and associations having web sites;

- Sufficient funds to implement Phase I (education);

- Mutual trust between the local Maasai community committed to giving up the practice of FGM (and at the same time improving their social and economic conditions) and western society sensitive to and concerned by the infringement of human rights.

\section{TIMETABLE OUTLINE}

Phase 1 has already been started on a small-scale, voluntary basis.

Phase 2 is in progress. Three women's groups (totalling 80 women) against FGM have already been formed and are preparing to sell Maasai jewellery (bracelets).

Phase 3 will be soon in place as many contacts have been made in order to establish a worldwide partnership 


\section{FINANCIAL RESOURCES}

The education phase 1 must find external financial resources (sponsors). The project period has therefore been projected at 3 years. The project will be implemented at Mau division first (77,686 people spread among 16,704 households). With a budget of $100^{\prime} 000$ Euro/year, we plan to visit and sensitise 1500 households by year, employing 10 social workers or nurses. We are expecting a redaction in the prevalence of FGM and forced marriages among the target group by 50\% at least within the first 6 months.

The sale of "Maasai bracelets of solidarity" is a cyclic sustainable process, having a variable time life (this is the period during which a women's group against FGM will be financially assisted) and variable extent (the area covered by our campaign will be proportional to our financial resources).

We hope to receive funds from UNESCO, UNIFEM, WHO or other international bodies.

\section{ACKNOWLEDGEMENT}

\section{M.E.D (kenyan NGO) Maasai Education Discovery}

- Mr. KOITAMET OLEKINA, P.O. Box 788, Narok, Kenya - Tel / Fax :

254-0305-23066, e-mail : Info@maasaieducation.org - Website:

www.maasaieducation.org

- M.E.D, Mr. LEDAMA OLEKINA (President), 2 Park Plaza, Suite 415, Boston, MA 02116 USA, Tel : 001-617-7790619, Fax : 001-6174263490.

\section{BIOGRAPHY}

Annie Corsini-Karagouni obtained a license in mathematics at the University of Athens in 1976. After that she received a third cycle diploma in Astronomy and Astrophysics in 1982 at the Geneva Observatory in Sauverny. Over the last 12 years she has worked for different financial institutions in Switzerland as a database administrator in IS departments. In parallel, Annie is active in various human rights and social organisations as a volunteer. She is a committee member of Business and Professional Women club (BPW) in Geneva, helps in the "Association Bleu Ciel" that is working in Rwanda, and she helps in "Sentinelles", a children rescuing Foundation in Lausanne. She is Maasai Education Discovery's director since two years and has a good contact with representatives of the Maasai community. 